DOI: $10.20472 / E S .2020 .9 .2 .001$

\title{
THE SEARCH FOR DETERMINANTS OF KOSOVAN SMALL AND MEDIUM ENTERPRISES PERFORMANCE
}

\author{
AJTENE AVDULLAHI, AVDULLAH HOTI
}

\begin{abstract}
:
The main purpose of this study is to identify determinants of SMEs performance, followed by the impact of Information Technology on SMEs profitability. By reviewing the existing literature and using the secondary data, this paper empirically investigates the determinants of SMEs growth in Kosovo; the fundamental obstacles faced by SMEs in Kosovo; the impact of Information Technology on SMEs performance and, it proposes strategies and measures to maximise Information Technology adoption from Kosovan SMEs. For the research purpose in this paper are used the secondary data gathered from Business Support Center Kosovo, who developed a survey from 500 SMEs in Kosovo. The combination of the variables related to entrepreneur, firm, business environment and IT adoption in a logit regression model suggest that entrepreneurs age, business age, introduction of any new method of marketing other than existing in the market for products/services during last three years from the firm are significant, whereas Internet use from SMEs resulted the most significant variable for SMEs profitability.
\end{abstract}

\section{Keywords:}

Business obstacles, Entrepreneur's related factors, Firm's related factors, Information Technology, Internet, SMEs profitability

JEL Classification: L25, L26, M15

\section{Authors:}

AJTENE AVDULLAHI, Faculty of Economics, University of Mitrovica "Isa Boletini", Kosovo, Email: ajtene.avdullahi@umib.net

AVDULLAH HOTI, Faculty of Economics, University of Prishtina, Kosovo, Email: avdullahi.hoti@uni-pr.edu

\section{Citation:}

AJTENE AVDULLAHI, AVDULLAH HOTI (2020). The search for determinants of Kosovan Small and Medium Enterprises performance. International Journal of Economic Sciences, Vol. IX(2), pp. 1-22., 10.20472/ES.2020.9.2.001 


\section{Introduction}

Small and medium enterprises are generators of employment and contribute to the economic development of both developed and developing countries, Thus Peric \& Kukec (2013) indicate that SMEs are of high importance in every country and in the world The first cross-country evidence on the links between SMEs, economic growth, and poverty alleviation, was provided by Beck et al. (2006) using a new database with a sample of over 10,000 firms from 80 countries. Most of the prior studies focused on the business environment and its impact on SMEs growth. Some studies focused on SMEs intention to adopt Information Technology. The lack of combinations of different factors such as business environment, entrepreneur's resources, firm and, IT adoption and their influence on SMEs performance in transition economies raised our concern and curiosity to develop this study.

According to Hofer and Sonberg (1987) the new venture performance is a function of the entrepreneur, industry structure, and strategy. This model was extended by including resources, organizational structure, processes, and systems (Chrisman, Bauerschmidt, \& Hofner, 1998). According to Chrisman, Bauerschmidt, \& Hofner, (1998) the strategy despite its importance is as good as the resources it deploys and the structure processes, and systems the venture uses to implement it.

Pflugoeft et al. (2003) stressed that the sophistication of small businesses with information technology is a critical factor in the level of e-business deployment. Information technology matters to business success since it affects directly the mechanisms through which they create and capture value to earn a profit: IT is thus integral to a firm's business-level strategy (Drnevich and Carson, 2013). Pratt (2002) argued that the findings of his study support the hypothesis that e-business affords new opportunities for success for small firms and particularly for niche businesses. With the increasing business potency of the Internet and IT adoption, global challenges and opportunities are being interconnected. Most of the business leaders have realised that their business must become e-business to maintain their competitive advantages. A business is an e-business as it uses the Internet as the fully integrated channel for all business activities. SMEs initially have used the Internet only for business issues, as a tool for communications and for surfing the World Wide Web. This adoption is followed by a higher level requiring the SME to register a URL and develop a Website, which can be viewed and accessed globally (Simmons, Armstrong, \& Durking, 2008). By reviewing the existing literature and using the secondary data this paper aims to empirically investigate the determinants of SMEs growth in Kosovo; the fundamental obstacles faced by SMEs in Kosovo; the impact of Information Technology on SMEs performance and, it proposes strategies and measures to maximise Information Technology adoption from Kosovan SMEs. By drawing the research from Kosovo, this study provides a contextualised view of determinants of SMEs performance in terms of profitability with a particular focus on IT adoption thus enabling the understanding of the context in this field.

\section{Literature review, Research Questions and Hypothesis}

Earlier it was supposed that economic development will take place with large investments made by large enterprises by creating scale economies. Numerous factors such as changes in the 
industrial structure, efficiency improvements and development of new markets reinstated focus in the SMEs as an instrument of economic growth and employment. According to Matejun, M. (2013) the beneficial influence of SMEs on the economic and social reality depends on the continuous development of those firms Although, the international community channels a huge amount of aid into supporting SMEs (Biggs, 2002), still some authors highlight the advantages of large firms such as ability to exploit economies of scale and more easily undertake the fixed costs associated with research and development $(R \& D)$ with positive productivity effects (Pack \& Westphal, 1986; Beck et al., 2006).

The firm's performance and profitability depends heavily on the business environment, therefore the ability to adapt to business environment presents a strength for the company (Avdullahi \& Fejza, 2015). The new venture performance is a function of the decisions and behaviors of entrepreneurs in recognizing environmental opportunity. Cliff (1998) rightly stressed that not all firms experience the same growth. Therefore, limited growth is not always associated with the inability to grow. It may be reflective of rather objective of the entrepreneur to grow the firm-i.e., short-term view.

\subsection{Research Questions}

The overall purpose of this study is to contribute to the existing theory with empirical evidence from a unique transitional country - Kosovo. Considering the context of the research, the primary purpose of this study is to investigate the determinants of SMEs profitability in Kosovo. This paper elaborates on the path taken to answer the following research questions:

RQ1: Which are the main determinants of SMEs growth in Kosovo in terms of SMEs profitability?

RQ2: Does Information Technology adoption influence in SMEs performance?

Given the available evidence on transition countries (Kontorovich, 1999; Bartlett and Bukivc, 2001; Bartlett, Bateman, and Vehovec, 2002; BSCK, 2012) the business environment is heavily characterised by institutional barriers both formal and informal. In this context, we are particularly interested in how formal and informal barriers influence the SMEs profitability in Kosovo. According to Avdullahi (2015) SMEs are more concerned with the external environment obstacle rather than with internal factors such as managerial or employee's skills and education.

\subsection{Hypothesis}

This research will include internal and external factors that could influence SMEs performance. The elements are summarized as: the nature and characteristic of the business environment - the barriers to doing business in Kosovo, determinants of SMEs performance, the managerial characteristics and IT adoption. This paper is focused on how the factors interact to determine the SMEs performance in terms of profitability. In this study, we will test four groups of the independent variable. Similarly, aiming to answer the first research question RQ1 the following hypotheses are set and ranked into four main groups.

Human capital - It is hypothesized that Entrepreneur's attributes, e.g. age, education and previous business experience will be positively related to SMEs performance. The following three sub-hypotheses are set to explore each attribute of human resources separately:

Hypothesis 1a: Entrepreneur's age, will be positively related to SMEs performance, 
Hypothesis 1b: Entrepreneur's Education, will be positively related to SMEs performance, Hypothesis 1c: Entrepreneur's previous business experience will be positively related to SMEs performance.

Studies indicate that there is a positive correlation between the degree of management training and the performance of an SME (Cosh, et al., 2000). Therefore, the following hypothesis is set:

Hypothesis 2: Managers training in management and business will be positively related to SMEs performance.

Environment-related factors - SMEs operating in transition economies face numerous formal and informal barriers. The business environment remains crucial to SMEs performance. Besides, the firm's growth and performance are influenced by many other complex external and internal factors. In this research, it is hypothesized that formal and informal institutional barriers have a negative impact on SMEs performance.

Hypothesis 3: Formal and informal institutional barriers are negatively related to SMEs performance.

Four sub-hypotheses are set, to distinguish the impact of the formal and informal barrier on firm's performance. We expect all formal and informal barriers to hinder SMEs profitability. Dadashev et al. (2003) declared that high taxation in Russia increased the shadow economy and unprofitable businesses. Thus, we suppose that higher taxes as a formal barrier will have a negative influence on the firm's profitability.

Hypothesis 3a: Taxes too high are negatively related to SMEs performance.

Informal institutions present codes of behavior, norms, and culture, which are not supported by formal law but by social custom (North, 1990). The informal barriers such as the corruption (Bohata and Mladek, 1999), strong competition and unfair competition from the large informal economy (Muent, Pissarides, \& Sanfey, 2001) affect doing business in transition economies; therefore, the following sub-hypothesis are set:

Hypothesis 3b: Strong competition will be negatively related to SMEs performance,

Hypothesis 3c: Corruption is negatively related to SMEs performance,

Hypothesis 3d: Informal economy is negatively related to SMEs performance.

Firm related characteristics - The firm's age, size, location and sector influence SMEs performance, therefore hypothesis 4 and three sub-hypothesis are set.

Hypothesis 4: Business age, size and sector are positively related to SMEs performance

Hypothesis 4a: Business age is positively related to SMEs performance,

Hypothesis 4b: Business size is positively related to SMEs performance,

Hypothesis 4c: Business service sector is positively related to SMEs performance

Firms strategy - Entrepreneurs start up and run their companies by following different growth strategies. Existing literature suggests strategic decisions "how the ventures are growing" (i.e., via internal or external growth) and "where that growth is occurring" (i.e., domestically or internationally), whereas growth through mechanisms internal to the firm means that the 
enterprise uses innovative product development, technological sophistication or marketing practices to identify and develop products (Gilbert, McDougall, \& Audretsch, 2006). We hypothesize that firm's strategic decision to introduce new methods of marketing other than existing and the company's investments (Hypothesis: 5,6 ) have the positive impact on SMEs profitability.

Hypothesis 5: Firm's introduction of any new method of marketing during the last three years is positively related to SMEs performance.

Hypothesis 6: Firm's Investment is positively related to SMEs performance.

Regarding the second research question RQ2, we hypothesize that IT adoption will have the positive influence on SMEs performance (Hypothesis: 7 and sub-hypothesis 7a,7b,7c).

Hypothesis 7: Information Technology adoption by the company is positively related to SMEs performance.

Hypothesis 7a: Internet usage by the company is positively related to SMEs performance.

Hypothesis 7b: Computer usage by the company is positively related to SMEs performance.

Hypothesis 7c: Website usage by the company is positively related to SMEs performance.

\section{Data description and methodology}

The methodological position of the present research rests on the use of the quantitative analyses. For research purpose of this study, we will use secondary data gathered from Business Support Center Kosovo, who developed a survey from 500 SMEs in Kosovo carried out in December 2012. This survey includes these sectors: service, trade, and manufacturing. In the sample are included SMEs across all regions of Kosovo. According to BSCK (2013), the sample is drawn randomly from the business register that was kept at the Ministry of Trade and Industry-Agency for Business Registration and, it was designed to study SMEs profile and entrepreneurship. The BSCK research team has stratified the sample into two categories: the size of the company and sectors of business activity as seen in Table 1.

Table 1 Total sample by sector and size (number of firms)

\begin{tabular}{|c|c|c|c|c|}
\hline Sector & Micro & Small & Medium & Total \\
\hline Manufacturing & 34 & 24 & 6 & 115 \\
\hline Service & 140 & 64 & 12 & 174 \\
\hline Trade & 176 & 37 & 7 & 211 \\
\hline Total & 350 & 125 & 25 & 500 \\
\hline
\end{tabular}

Source: BSCK SME Survey 2012 
BSCK team conducted interviews face-to-face with the key people in each enterprise, mainly owner/managers or financial managers.

\subsection{Dependent variable}

Since 1931, Gibrat's law was found as a useful theoretical benchmark for theoretical and empirical research on the determinants of firm growth (Becchetti and Trovato, 2002). The Gibrat's Law mainly was confirmed from the very early articles in the '50s, and '60s of the last century. The vast majority of the reviewed literature has rejected the Gibrat's Law. In the last few decades, the post-entry performance of firms has focused on researchers' attention. Post-entry performance includes analysis of a firm's growth and the likelihood of its survival. Kimberley (1976) stated the number of employees is the most widely used measure of size. Delmar et al. (2003) mentioned that the number of employees does not reflect "labour productivity increases, the machine for man substitution, the degree of integration, and other make-or-buy decisions". For our research purpose we will measure SMEs performance in terms of profitability.

\subsection{Independent Variables}

The post-entry firm behaviour is influenced by numerous factors. According to Storey (1994), a distinction is often made between three groups of growth determinants: those related to the entrepreneur; those related to the firm; and those related to strategy. In this research explanatory (independent) variables are separated into four main categories:

Human Capital related variables - In literature often a difference is made between the "generic" and "specific" components of human capital (Becker, 1975). Similar to some previous authors we argue that generic human capital refers to the general knowledge obtained by entrepreneurs or employees through regular education, whereas specific human capital refers to tacit skills and knowledge that are less transferable and have a narrower scope of applicability than generic human capital attributes (Gimeno, Folta, Cooper, \& Woo, 1997; Hoxha, 2013). We have included variable education as a proxy for general human capital. Entrepreneurs specified their level of education. We use this variable to measure whether (or not) entrepreneurs have a university degree ( $1=$ university degree and higher degrees, $0=$ otherwise). Entrepreneurs' previous business experience in the field they started their business is related to actual firm performance. Therefore, respondents were asked whether they had previous experience ( $1=y e s, 0=n o)$. We control for the age of the entrepreneur. Studies indicate that there is a positive correlation between the degree of management training and the performance of an SME (Cosh, Hughes, \& Weeks, 2000). Regarding specific human capital and strategic decisions in their further training, respondents were asked whether SMEs managers have received training in management or business-related fields ( $1=$ yes, $0=$ no). 
Environment related variables - The second group of variables is related to institutional constraints that are likely to have an impact on SMEs performance in the particular context of transition countries. In our research model, we have chosen 4 among 21 variables that according to the BSCK survey results present the main obstacles to business. The respondent's answers whether strong competition, informal economy, corruption and taxes too high presents obstacles to business ( $1=$ is an obstacle, $0=$ is not an obstacle).

Firm related variables - According to Gibrat Law the probability of given proportionate change in size during a particular period is the same for all firms in a given industry (Gibrat, 1931), that implies that both growths mean, and variance does not show any relationship with the size of the firm. In contrast, Jovanovic's model of noisy selection indicates new firms have no expectations about their post-entry performance so that the likelihood of survival should be assumed to be stochastically distributed across firms, whereas firms learn about their efficiency as they operate in the industry (Jovanovic, 1982). Also, Jovanovic (1982) assert the efficient firms grow and survive whereas inefficient firms decline and fail. In markets with only negligible-scale economies, the likelihood of survival is higher for new firms, but the opportunity to grow in the post-entry period is limited by the gap between the minimum efficient scale and the size of the firm (Acs and Audretsch, 2001; Krasniqi B., 2007). We also control for the industry sector. Three main sector dummies are included: manufacturing, trade and services. Variables business size (number of current employees) and business age (measured as the number of years the firm has been founded) are included as well. Business age, size and sector served as control variables in the model for performance to capture the potential effect of firm profitability and subsequent growth.

Firms strategy variables - The fourth group of variables describes general characteristics of the firm as controls that may influence SMEs performance. We include a variable measuring whether the company has made investments in 2012 ( $1=y e s, 0=$ no). The rationale is that the higher the amount of investments will increase the return on investments and firm's profit. According to Gilbert et al. (2006) growth through internal mechanisms to the firm occur when enterprise uses innovative product development or marketing practices to identify and develop products. Therefore we included a firm related strategy variable new method of marketing whereas respondents had to answer whether their firm introduced any new method of marketing other than existing in the market for product/service during last three years ( $1=y e s, 0=$ no). Expecting that the firm's internationalisation could increase profitability we included a variable export of the company whereas respondents had to declare whether their enterprise is an exporting firm ( $1=y e s, 0=$ no). InformationTechnology - adoption resides and complies with the Firms strategy. Information technology adoption has been an important topic of study in many areas including SMEs. It is 
expected that IT can reduce labour costs and increase profit, add value to products and services and increase a company's competitive advantage (Corso, Martini, Pellegrini, \& Paolucci, 2003; Levy, Powell, \& Yetton, 2001; Nguyen, Sherif, \& Newby, 2007 and Premkumar, 2003). Therefore, the last group of variables describes the level of technology usage from Kosovan SMEs that can influence SMEs performance. A variable is included measuring whether the firm declared they have computer/s, and we also ask if firms are using the Internet ( $1=y e s, 0=n o)$. A variable is set measuring whether the firm reported that have their website and web e-mail ( $1=y e s, 0=$ no) (Table 2).

Table 2 List of variables

\begin{tabular}{|c|c|c|}
\hline Category & Variables & Definition \\
\hline \multirow{4}{*}{$\begin{array}{l}\text { Human } \\
\text { Capital }\end{array}$} & Age & Age of the entrepreneur in years \\
\hline & Education & $\begin{array}{l}1=\text { if the entrepreneur has university degree, } 0= \\
\text { otherwise }\end{array}$ \\
\hline & Business experiences & $1=$ yes, $0=$ no \\
\hline & $\begin{array}{l}\text { Business } \\
\text { Management Training }\end{array}$ & $\begin{array}{l}1=\text { if the entrepreneur followed training in last } \\
\text { two years }\end{array}$ \\
\hline \multirow{3}{*}{ Firm } & Business Age & Number of years the firm has been operating \\
\hline & Business Size & $\begin{array}{l}\text { How many employee your firm has actually in } \\
2012 \text { (indicate number)? }\end{array}$ \\
\hline & Sector Service & $\begin{array}{l}1=\text { if the firms operates in service sector, } 0= \\
\text { otherwise }\end{array}$ \\
\hline \multirow{3}{*}{ Barriers } & Informal economy & $1=$ is a barrier, $0=$ is not a barrier \\
\hline & Corruption & $1=$ is a barrier, $0=$ is not a barrier \\
\hline & Taxes to high & $1=$ is a barrier, $0=$ is not a barrier \\
\hline \multirow{3}{*}{ Strategy } & $\begin{array}{l}\text { Strong competition } \\
\text { Exporting firms }\end{array}$ & $\begin{array}{l}1=\text { is a barrier, } 0=\text { is not a barrier } \\
1=\text { yes, } 0=\text { no }\end{array}$ \\
\hline & Investment 2012 & $1=$ yes, $0=$ no \\
\hline & Marketing method & $1=$ yes, $0=$ no \\
\hline \multirow{3}{*}{ IT } & Computer & $1=$ yes, $0=$ no \\
\hline & Internet use & $1=$ yes, $0=$ no \\
\hline & Web site & $1=$ yes, $0=$ no \\
\hline
\end{tabular}

\section{Results and discussion}

In this chapter, the obtained results of this study are presented. Initially, is given a brief overview of the descriptive results and correlations of the main variables introduced in the regression analysis. Afterwards, the research model on SMEs performance in terms of profitability is 
discussed. As can be seen in Table 3 most of the entrepreneurs/owners of the surveyed firms are young, and the average age of the respondents is 37 years. Business age (years of operation) is higher than ten years.

\begin{tabular}{llllll}
\multicolumn{6}{l}{ Table 3 Descriptive Statistics } \\
\hline N & Min & Max & Mean & $\begin{array}{l}\text { Std. } \\
\text { Deviation }\end{array}$ \\
\hline AGE & 495 & 17 & 78 & 37.38 & 11.183 \\
EDUC & 486 & 0 & 1 & 0.38 & 0.487 \\
BUSINEXPER & 467 & 0 & 1 & 0.73 & 0.447 \\
BUSMANTRAIN & 496 & 0 & 1 & 0.33 & 0.471 \\
INFORMECON & 453 & 0 & 1 & 0.86 & 0.344 \\
CORRUPT & 477 & 0 & 1 & 0.84 & 0.37 \\
TAX & 478 & 0 & 1 & 0.88 & 0.322 \\
STRONCOMPET & 474 & 0 & 1 & 0.49 & 0.5 \\
BUSINAGE & 466 & 0 & 73 & 10.32 & 9.012 \\
BUSINSIZE & 483 & 1 & 120 & 12.47 & 11.606 \\
SECSERVICE & 349 & 0 & 1 & 0.32 & 0.467 \\
INVEST2012 & 485 & 0 & 1 & 0.39 & 0.488 \\
EXPOFIRM & 457 & 0 & 1 & 0.06 & 0.236 \\
NMARKEMETH & 466 & 0 & 1 & 0.11 & 0.307 \\
COMPUT & 498 & 0 & 1 & 0.58 & 0.494 \\
INTERNETUSE & 434 & 0 & 1 & 0.73 & 0.447 \\
FWEBSITE & 424 & 0 & 1 & 0.16 & 0.363 \\
\hline
\end{tabular}

\subsection{Discussion of research model}

In this section, we discuss the econometric model designed to investigate the factors influencing the probability of firms being profitable. The logit model is chosen because our dependent variable is dichotomous taking values of 1 if the firm is profitable and taking the value of 0 if not profitable. The Wooldridge (2006) logistic model takes the following form:

$$
P(y=1 \mid x)=\beta_{0}+\beta_{1} x_{1}+\ldots+\beta_{k} x_{k}
$$

Where the outcome of $y$ is equal to 1 if the company belongs to the group of profitable firms and 0 otherwise; while $\mathrm{x}$ is a vector of explanatory variables and is the vector of coefficients of independent variables in the model. Based on the logistic model we estimated following the empirical model to measure the impact of firm, entrepreneur, business environment business strategy and IT related factors on the probability of being profitable: 


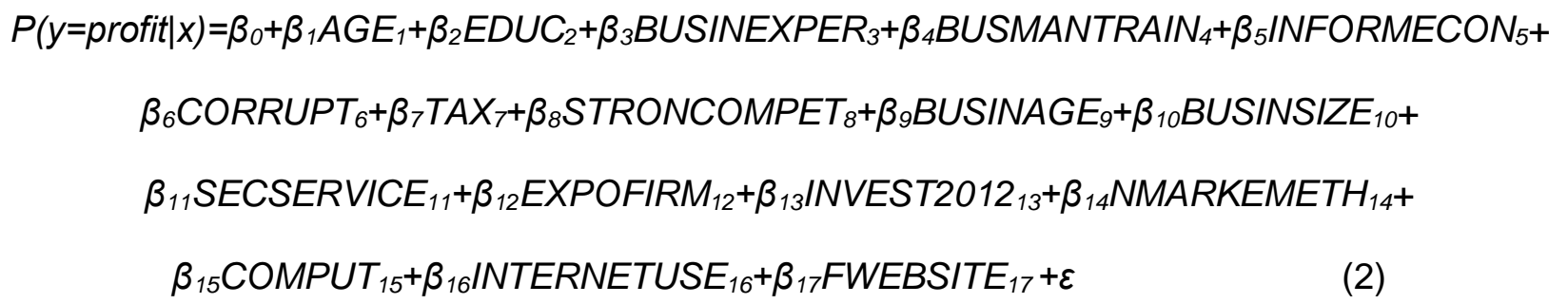

\subsection{Discussion of results}

Initially, we begin with the test for overall statistical significance of coefficients in the model. Table 4 shows that all parameters (coefficients) are jointly and statistically different from zero. All pvalues are .000 , based on which we can conclude that our coefficients in the model have the explanatory power to explain the profitability of firms.

Table 4 Omnibus Tests of Model Coefficients

\begin{tabular}{lllll}
\hline & & Chi-square & df & Sig. \\
\hline Step 1 & Step & 51.223 & 17 & 0 \\
& Block & 51.223 & 17 & 0 \\
& Model & 51.223 & 17 & 0 \\
\hline
\end{tabular}

According to the Cox \& Snell $R$ Square statistical tests as well Nagelkerke $R$ Square in Table 5 the econometric model has very high explanatory power. In particular in this type of crosssectional data and models. According to these statistical tests, the independent variables included in the model explain around 33 percent of the variation in the dependent variable, i.e. the profitability of firms.

Table 5 Model Summary

\begin{tabular}{|c|c|c|}
\hline $\begin{array}{l}\text { Ste } \\
\mathrm{p}\end{array}$ & -2 Log likelihood & $\begin{array}{lll}\text { Cox \& Snell } & \mathrm{R} \text { Nagelkerke R Square } \\
\text { Square } & & \\
\end{array}$ \\
\hline 1 & $191.302^{a}$ & .245 \\
\hline
\end{tabular}

The classification table produced by SPSS output summarises the results of our predictions of firm profitability of the model based on our 17 independent variables. Our model can predict 57.1 percent of non-profitable firms and 82.1 percent of profitable firms. In general, our model can predict 72.5 percent of firms correctly (Table 6). 
Table 6 Classification Table

\begin{tabular}{|c|c|c|c|c|c|}
\hline & \multicolumn{2}{|c|}{ Observed } & \multicolumn{3}{|c|}{ Predicted } \\
\hline & & & \multicolumn{2}{|c|}{ PROFIT } & \multirow{2}{*}{$\begin{array}{l}\text { Percentage } \\
\text { Correct }\end{array}$} \\
\hline & & & 0 & 1 & \\
\hline \multirow[t]{4}{*}{ Step 1} & PROFIT & 0 & 40 & 30 & 57.1 \\
\hline & & 1 & 20 & 92 & 82.1 \\
\hline & \multicolumn{4}{|l|}{ Overall } & \\
\hline & \multicolumn{4}{|c|}{ Percentage } & $1<.3$ \\
\hline
\end{tabular}

(a. The cut value is .500)

Now we will discuss the impact of independent variables on the dependent variable. The table below, reports results from the logistic regression in which we included 17 independent variables related to entrepreneur, firm, business environment, business strategy and information technology adoption. Some of the independent variables serve as a control and to improve model fits such as the firm's age, size, and sector variables (Table 7). These are the values for the logistic regression equation for predicting the dependent variable from the independent variable. They are in log-odds units. Similar to OLS regression, the prediction equation is expressed in terms of the variables used in this example, the logistic regression equation is:

$$
\begin{aligned}
P(y=\text { profit } / x)=.864-.052 A G E+.633 E D U C+.177 B U S I N E X P E R & -.269 B U S M A N T R A I N \\
& +.019 I N F O R M E C O N+.420 C O R R U P T-.966 \text { TAX }+.697 S T R O N C O M P E T+ \\
& .050 B U S I N A G E+.008 B U S I N S I Z E+.413 S E C S E R V I C E+.255 E X P O F I R M
\end{aligned}
$$$$
\text { -789INVEST2012+1.864NMARKEMETH-.248COMPUT +1.725INTERNETUSE +- }
$$$$
.535 F W E B S I T E+\varepsilon
$$

where $\mathrm{P}$ is the probability of SMEs being profitable. 
Table 7: Results from the logit model estimates: factors influencing the probability of being profitable firm

\begin{tabular}{|c|c|c|c|c|c|c|c|}
\hline \\
\hline \multicolumn{8}{|c|}{ Variables in the Equation } \\
\hline Step & AGE & -.052 & .018 & 8.143 & 1 & .004 & .950 \\
\hline \multirow[t]{17}{*}{$1^{a}$} & EDUCATION & .633 & .396 & 2.557 & 1 & .110 & 1.882 \\
\hline & BUSINEXPER & .177 & .411 & .185 & 1 & .667 & 1.193 \\
\hline & INFORMECON & .019 & .714 & .001 & 1 & .979 & 1.019 \\
\hline & COMPUT & -.248 & .507 & .240 & 1 & .624 & .780 \\
\hline & TAX & -.966 & .771 & 1.570 & 1 & .210 & .381 \\
\hline & $\begin{array}{l}\text { STRONCOMP } \\
\text { ET }\end{array}$ & .697 & .384 & .295 & 1 & .069 & 008 \\
\hline & BUSINAGE & .050 & .025 & 4.081 & 1 & .043 & 1.051 \\
\hline & BUSINSIZE & .008 & .007 & 1.227 & 1 & .268 & 1.008 \\
\hline & SECSERVICE & .413 & .433 & .910 & 1 & .340 & 1.511 \\
\hline & $\begin{array}{l}\text { BUSMANTRAI } \\
N\end{array}$ & -.269 & .423 & .406 & 1 & .524 & .104 \\
\hline & INVEST2012 & -.789 & .433 & 3.322 & 1 & .068 & .454 \\
\hline & EXPOFIRM & .255 & .712 & .128 & 1 & .721 & 1.290 \\
\hline & NMARKEMETH & 1.864 & .869 & 4.605 & 1 & .032 & 6.451 \\
\hline & CORRUPT & .420 & .627 & .448 & 1 & .503 & 1.522 \\
\hline & INTERNETUSE & 1.725 & .512 & 11.349 & 1 & .001 & 5.614 \\
\hline & FWEBSITE & -.535 & .613 & .761 & 1 & .383 & .586 \\
\hline & Constant & .864 & 1.251 & .477 & 1 & .490 & 2.372 \\
\hline
\end{tabular}

a. Variable(s) entered on step 1: AGE, EDUC, BUSINEXPER, INFORMECON, COMPUT, TAX, STRONCOMPET, BUSINAGE, BUSINSIZE, SECSERVICE, BUSMANTRAIN, INVEST2012, EXPOFIRM, NMARKEMETH, CORRUPT, INTERNETUSE, FWEBSITE

(Dependent variable is categorical $1=$ profitable firm and $0=$ non-profitable firm)

Table 7 reports the series of regression results that presents the importance of factors explaining the determinants of SMEs performance in terms of profitability. Although findings indicate that several correlations coefficients are found to be significant, those correlations are sufficient low resulting that our model passes the Wald test for mutual statistical significance of independent variables resulting that they are mutually significantly different from zero (Wooldridge, 2006).

Besides, correlation matrix reported in Table 8 suggests low correlation coefficients in accordance with Lind et al. (2000) whereas rule of thumb for the detection of the multicollinearity problem a correlation coefficient is a threshold smaller than 0.7 in absolute value. Therefore, we can conclude that multicollinearity is not a problem in our data. 
Table 8 Correlation Matrix

\begin{tabular}{|c|c|c|c|c|c|c|c|c|c|c|c|c|c|c|c|c|c|}
\hline & & 軗 & U & 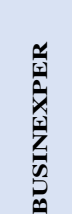 & 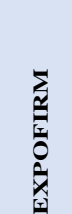 & 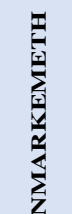 & $\sum_{0}^{5}$ & 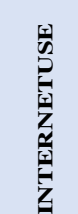 & 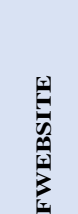 & 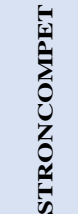 & 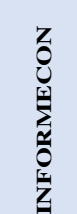 & 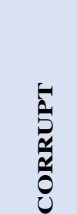 & 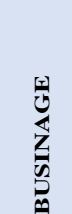 & 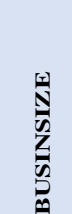 & 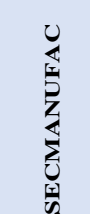 & 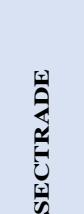 & 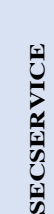 \\
\hline \multirow{3}{*}{ AGE } & Pearson Correlation & 1 & & & & & & & & & & & & & & & \\
\hline & Sig. (2-tailed) & & & & & & & & & & & & & & & & \\
\hline & $\mathrm{N}$ & 495 & & & & & & & & & & & & & & & \\
\hline \multirow{3}{*}{ EDUC } & Pearson Correlation & -.043 & 1 & & & & & & & & & & & & & & \\
\hline & Sig. (2-tailed) & .348 & & & & & & & & & & & & & & & \\
\hline & $\mathrm{N}$ & 482 & 486 & & & & & & & & & & & & & & \\
\hline \multirow{3}{*}{ BUSINEXPER } & Pearson Correlation & .016 & .077 & 1 & & & & & & & & & & & & & \\
\hline & Sig. (2-tailed) & .724 & .103 & & & & & & & & & & & & & & \\
\hline & $\mathrm{N}$ & 464 & 453 & 467 & & & & & & & & & & & & & \\
\hline \multirow{3}{*}{ EXPOFIRM } & Pearson Correlation & .050 & $.167^{3 *}$ & .056 & 1 & & & & & & & & & & & & \\
\hline & Sig. (2-tailed) & .286 & .000 & .250 & & & & & & & & & & & & & \\
\hline & $\mathrm{N}$ & 453 & 444 & 426 & 457 & & & & & & & & & & & & \\
\hline \multirow{3}{*}{ NMARKEMETH } & Pearson Correlation & -.004 & .042 & .082 & $.102^{*}$ & 1 & & & & & & & & & & & \\
\hline & Sig. (2-tailed) & .938 & .370 & .087 & .034 & & & & & & & & & & & & \\
\hline & $\mathrm{N}$ & 463 & 454 & 437 & 429 & 466 & & & & & & & & & & & \\
\hline \multirow{3}{*}{ COMPUT } & Pearson Correlation & -.051 & $.308^{* *}$ & $.213^{* *}$ & $.178^{* *}$ & $.137^{* *}$ & 1 & & & & & & & & & & \\
\hline & Sig. (2-tailed) & .262 & .000 & .000 & .000 & .003 & & & & & & & & & & & \\
\hline & $\mathrm{N}$ & 494 & 485 & 465 & 456 & 465 & 498 & & & & & & & & & & \\
\hline \multirow{3}{*}{ INTERNETUSE } & Pearson Correlation & -.025 & $.203^{* *}$ & $.198^{* *}$ & $.159^{* *}$ & $.154^{* *}$ & $.562^{* *}$ & 1 & & & & & & & & & \\
\hline & Sig. (2-tailed) & .611 & .000 & .000 & .001 & .002 & .000 & & & & & & & & & & \\
\hline & $\mathrm{N}$ & 430 & 421 & 405 & 395 & 408 & 434 & 434 & & & & & & & & & \\
\hline \multirow{3}{*}{ FWEBSITE } & Pearson Correlation & .072 & $.168^{* *}$ & .084 & $.282^{* *}$ & $.294^{* *}$ & $.273^{* *}$ & $.222^{* *}$ & 1 & & & & & & & & \\
\hline & Sig. (2-tailed) & .142 & .001 & .095 & .000 & .000 & .000 & .000 & & & & & & & & & \\
\hline & $\mathrm{N}$ & 420 & 413 & 395 & 385 & 394 & 424 & 404 & 424 & & & & & & & & \\
\hline \multirow{3}{*}{ STRONCOMPET } & Pearson Correlation & -.073 & $.134^{* *}$ & .070 & -.002 & .091 & $.171^{* *}$ & $.246^{* *}$ & $.129^{* * 3}$ & 1 & & & & & & & \\
\hline & Sig. (2-tailed) & .114 & .004 & .143 & .968 & .056 & .000 & .000 & .010 & & & & & & & & \\
\hline & $\mathrm{N}$ & 469 & 460 & 444 & 436 & 445 & 472 & 410 & 401 & 474 & & & & & & & \\
\hline \multirow{3}{*}{ INFORMECON } & Pearson Correlation & -.065 & .082 & .001 & .071 & .034 & -.031 & $-.126^{*}$ & .006 & $-.097^{*}$ & 1 & & & & & & \\
\hline & Sig. (2-tailed) & .168 & .087 & .984 & .146 & .478 & .517 & .012 & .911 & .041 & & & & & & & \\
\hline & $\mathrm{N}$ & 448 & 439 & 425 & 416 & 427 & 451 & 393 & 382 & 442 & 453 & & & & & & \\
\hline \multirow{3}{*}{ CORRUPT } & Pearson Correlation & $-.171^{* *}$ & -.063 & -.007 & .004 & .017 & $\begin{array}{l}-.01 \\
.018\end{array}$ & $-.119^{*}$ & $-.124^{*}$ & $-.125^{8 *}$ & $.318^{* * *}$ & 1 & & & & & \\
\hline & Sig. (2-tailed) & .000 & .175 & .877 & .932 & .721 & .691 & .016 & .012 & .007 & .000 & & & & & & \\
\hline & $\mathrm{N}$ & 472 & 463 & 447 & 438 & 448 & 475 & 413 & 405 & 467 & 447 & 477 & & & & & \\
\hline \multirow{3}{*}{ BUSINAGE } & Pearson Correlation & $.313^{* * 4}$ & .039 & .041 & $.111^{*}$ & .068 & .017 & -.021 & .093 & -.058 & -.023 & $-.128^{* *}$ & 1 & & & & \\
\hline & Sig. (2-tailed) & .000 & .402 & .396 & .023 & .156 & .715 & .677 & .066 & .226 & .631 & .007 & & & & & \\
\hline & $\mathrm{N}$ & 464 & 454 & 439 & 425 & 435 & 465 & 403 & 394 & 443 & 428 & 444 & 466 & & & & \\
\hline \multirow{3}{*}{ BUSINSIZE } & Pearson Correlation & .038 & $.098^{*}$ & .069 & $.308^{* *}$ & $.153^{* *}$ & $.135^{* *}$ & .084 & $.306^{* *}$ & .046 & .006 & .018 & .067 & 1 & & & \\
\hline & Sig. (2-tailed) & .406 & .035 & .144 & .000 & .001 & .003 & .086 & .000 & .321 & .895 & .696 & .156 & & & & \\
\hline & $\mathrm{N}$ & 478 & 469 & 454 & 444 & 451 & 482 & 419 & 413 & 458 & 437 & 461 & 450 & 483 & & & \\
\hline \multirow{3}{*}{ SECMANUFAC } & Pearson Correlation & .091 & .023 & .070 & $.252^{* *}$ & $.169^{* *}$ & .105 & .107 & $.189^{* * 3}$ & .010 & -.073 & -.013 & .070 & .094 & 1 & & \\
\hline & Sig. (2-tailed) & .093 & .676 & .206 & .000 & .002 & .050 & .064 & .001 & .858 & .189 & .818 & .204 & .084 & & & \\
\hline & $\mathrm{N}$ & 345 & 345 & 331 & 321 & 324 & 347 & 299 & 295 & 337 & 322 & 339 & 330 & 337 & 348 & & \\
\hline \multirow{3}{*}{ SECTRADE } & Pearson Correlation & -.071 & .075 & -.053 & -.095 & -.013 & -.019 & .038 & -.035 & .092 & .081 & .027 & .042 & -.092 & $-.342^{* *}$ & 1 & \\
\hline & Sig. (2-tailed) & .185 & .163 & .329 & .086 & .812 & .720 & .504 & .545 & .091 & .145 & .611 & .441 & .089 & .000 & & \\
\hline & $\mathrm{N}$ & 350 & 350 & 336 & 326 & 328 & 352 & 304 & 299 & 342 & 327 & 344 & 335 & 342 & 348 & 353 & \\
\hline \multirow{3}{*}{ SECSERVICE } & Pearson Correlation & .047 & -.017 & -.042 & $-.122^{*}$ & -.088 & -.001 & -.086 & -.004 & $-.114^{*}$ & -.024 & $\begin{array}{c}.061 \\
.061\end{array}$ & $\begin{array}{l}-.087 \\
0.08\end{array}$ & $\begin{array}{l}.036 \\
.036\end{array}$ & $-.243^{* *}$ & $-.689^{* *}$ & 1 \\
\hline & Sig. (2-tailed) & .383 & .750 & .442 & .029 & .113 & .992 & .139 & .947 & .036 & .669 & .266 & .116 & .512 & .000 & .000 & \\
\hline & $\mathrm{N}$ & 346 & 346 & 332 & 322 & 325 & 348 & 300 & 295 & 338 & 323 & 340 & 331 & 338 & 348 & 349 & 349 \\
\hline
\end{tabular}

**. Correlation is significant at the 0.01 level (2-tailed).

*. Correlation is significant at the 0.05 level (2-tailed). 
Entrepreneur related factors - Regarding the first hypothesis concerning Entrepreneur's attributes, e.g. age, education and previous business experience will be positively related to SMEs performance, our findings indicate the age of the entrepreneur is highly statistically significant $(p=.004)$ and enters the equation with the negative sign. A unit change in the age of the entrepreneur decreases the odds ratio to be in-group of profitable firms by -.052 . Based on the existing literature the entrepreneur's characteristics such prior related industry experience (Cooper, Gimeno-Gascon, \& Woo, 1994; Eisenhardt and Schoonhoven, 1990; Siegel, Siegel, \& MacMillan, 1993), and prior entrepreneurial or start-up experiences (Box, White, \& Barr, 1994); have well established direct effects on growth of the new firms. In our research we found weak support for positive impact of variable entrepreneur's education to SMEs profitability $(p=.110)$, whereas variable business experience is not statistically significant in SMEs performance respectively profitability $(p=.667)$, this may suggest that there is a diminishing rate of return from the business experience as predicted by Jovanovic learning theory. When entrepreneurs enter the market, they have a knowledge gap in business practices. Therefore, the knowledge they acquire adds to their efficiency. However, after years they accumulate sufficient knowledge and the extra year of experience does not produce the same effect as at the beginning of their career. Even numerous of authors argue prior experience is vital to firm's growth; however, there are opposing opinions similar to our obtained results, e.g. "too much knowledge has been shown to have diminishing returns on the sales and employment growth of new firms" (Chrisman, McMullan, \& Hall, 2005). Furthermore our results concerning entrepreneur's prior experience are not in line with Cooper, Gimeno-Gascon, \& Woo (1994) theory indicating that entrepreneur's prior experience is of particular importance mainly due to the knowledge relevant for making business decisions which is often tacit and requires time spent to develop such knowledge activity is developed. The variable managers training in management and business is expected to have the positive effect on firm's profitability; surprisingly our research indicates the opposite as this variable enters the equation with a negative sign and is not statistically significant $(p=.524)$. These results are not in line with other studies (McPherson, 1996; Krasniqi B., 2012) that provide evidence for the importance of trained managers of the firm, but we can assume that: training was not provided to the key persons of the company or the quality of training was low..

Business environment factors - From business environment-related variables that represent obstacles to business such as taxes too high, corruption, informal economy, and strong competition although it is hypothesised that these four obstacles will be negatively related to SMEs performance, only strong competition is statistically significant $(p=.069)$. The variable strong competition in the equation has a positive sign indicating that the higher the competition 
makes the firm more efficient and innovative to reduce the cost of operation and as such increases the likelihood of being profitable. In general, this can be interpreted that the firms that are more concerned with strong competition are profitable firms. According to (Krasniqi B., 2012) informal activities and corruption contribute to an anti-competitive environment in which the market fails to allocate resources efficiently since some firms operate informally.

On the other hand, the profitable firms are not concerned with corruption, informal economy and taxes too high since the research results do not support our hypothesis that taxes too high, corruption, informal economy are negatively related to SMEs performance. Concerning variables taxes too high and corruption, our results are not in line with Fjeldstad, Kolstad, \& Nygaard (2006) indicating that taxes are perceived to be a major problem for both young and old firms and, the corruption that is perceived as a significant constraint on businesses. The informal economy presents an obstacle to SME development in Kosovo in general (Skenderi, Islami, \& Mulolli, 2017), but our results indicate that profitable SMEs are less concerned with informality.

Firm related factors - It is hypothesized that business age, size, and the sector will be positively related to SMEs performance. As can be seen in descriptive statistics in table 3 the median of the firm's age in the sample is around ten years. Findings show that variable BUSINAGE (Business age) is statistically significant at around 5 percent level of significance $(p=.043)$ and in the equation has positive sign strengthening the argument that Gibrat's Law does not hold in our research, whereas potentiating Jovanovic's learning theory. This suggests that an increase of one year in the age of the firm increases the odds-ratio of .050 to be profitable firm. Older firms are more likely to be profitable compared to younger firms. Two other variables business size $(\mathrm{p}=.268)$ and service sector $(\mathrm{p}=.340)$ enter the equation with a positive sign and are not statistically significant. Our results are contradictory to Hirsch, Schiefer, Gschwandtner, \& Hartmann (2014) results whereas the firm size and industry concentration are identified as the main drivers of performance and, to Isik, Unal, \& Unal (2017) suggesting that the firm size of the manufacturing the sector tends to have a positive influence on the profitability of the firm.

Strategy related factors - In hypothesis 5,6 and 7 we hypothesised that Firms strategic decision to: introduce new methods of marketing other than existing for the last three years, company's investments and IT adoption by the company will be positively related to SMEs performance in terms of profitability. Our results indicate introducing new methods of marketing is statistically significant on SMEs performance $(p=.032)$ and in the equation has a positive sign. Our results are in line with Fejza \& Bajrami (2019) suggesting that firms should utilize new, better and more efficient marketing strategies as well as focus on green marketing to enable the company to keep up with good image and grow. Companies that did invest in the previous year of the survey are 
less likely to be profitable in the subsequent period $(p=.068)$. Probably, this is linked to the domestic practices of business as firms sometimes make investment choices without taking into consideration the internal resources, cost of capital, and hence face difficulties in the subsequent period. Perhaps the companies have invested in long-term projects and expect returns in the coming years. This issue should be investigated further with qualitative data. Our results differ from Levasseur (2002) indicating that investing in relation to market expectations helps to combat competition pressure from other firms within or outside the industry, improving projected sales performance thus ensuring firm profitability.

Besides, the use of the Internet for new market research methods is an essential factor influencing the positive likelihood of being profitable firms.

Information Technology - Bartelsman \& Doms (2000), confirm the positive effects of ICT on firm performance in terms of productivity, profitability, market value and market share. From technology-related factors, variable use of the Internet is highly statistically significant at 1 percent, in the research equation has a positive sign. The variable Internet use shows that firms which use the Internet compared to firms that do not use the Internet are more likely to be profitable companies. Internet use has a critical role in the profitability of firms. The other technology-related variables such as the number of computers and website usage are not shown to be significant factors for profitability. In fact, the Internet is more important rather than the number of computers in the firm. Our results are not in line with findings of Rufai (2014), suggesting that the adoption of computer signalled an improvement in business performance of studied firms in terms of operational cost reduction, sale/customer increase, business expansion, increase profitability, improve service quality/delivery, fraud reduction and general operational and administrative efficiency. Similar to our results Notta \& Vlachvei (2013), indicate the low web-site adoption rate for the surveyed SMEs, as well as that the websites are mainly informative about the general characteristics of the firm such as location and contact. According to Sosa, Roy, \& Bautista, (2015) SMEs use social networks mainly to promote their business to their current and potential customers.

\section{Conclusions}

In general, this study contributes to the literature by bringing together a broad spectrum of variables, methods, and measures of profitability and applying them to SMEs dataset. Our findings indicate that four groups of variables (factors) are important to explain the firm's performance in terms of profitability. The age of the entrepreneur is highly statistically significant and decreases the odds ratio to be in-group of profitable firms. We found weak support for the 
positive impact of the entrepreneur's education to SMEs profitability, whereas the entrepreneurs' previous business experience in the field they started their business is not statistically significant in SMEs performance respectively profitability. Although it is expected that managers training in management and business, to have the positive effect on a firm's profitability, our research results indicate the opposite. From business environment-related variables, only strong competition is statistically significant. We believe that these results are the consequence of the unfavourable business environment from the past, during the '90s when most of the population working in state enterprises as a response to several political developments were expelled and were pushed to become entrepreneurs in order to survive. The push driven entrepreneurs were obliged to pay too high taxes. Therefore, most of them found the informal economy and corruption from officials in the state administration as the most appropriate solutions. It seems that most of the firms are adapted to this kind of business environment and to such obstacles. According to Bennett (2010), an entrepreneur chooses whether his or her enterprise will enter an industry formally or informally or, whether to stay out and this choice that is made under conditions of uncertainty about profitability. Whereas, enterprises that enter informally in the market, according to the start-up period performance, will decide whether to continue informally or, to switch formality status, or to exit. Informal employment is disadvantageous to workers as it comes without social benefits (World Bank, 2007). Bennett (2010) argues that Informality may be a stepping stone, without which formality may never be achieved. Business age is statistically significant indicating that the older firms are more likely to be profitable compared to younger firms. Whereas, companies that did invest in the previous year are less likely to be profitable in the subsequent period. Firms that use the Internet are more likely to be profitable companies. Therefore, we can conclude that Internet use has a critical role in the profitability of firms. Whereas, the number of computers that firms have and website usage are not shown to be significant factors for profitability. The econometric analysis provides a picture of the main determinants of SMEs performance in Kosovo. The Internet use remains the most significant variable on the firm's profitability. The analysis suggests that internal and external factors are both important in explaining the SMEs profitable model. Concerning theoretical implication, this study suggests using numerous factors, a combined model and a mixed approach to obtain the comprehensive overview on investigating SMEs performance. The obtained results address some practical implications for entrepreneurs. Taken into consideration the strong competition, we suggest to entrepreneurs/firms, to improve operational efficiencies and reduce costs and merely support existing processes with fewer resources. Entrepreneurs should introduce a new method of marketing other than existing in the market to increase the firm's profitability. Considering the high level of usage of social media in 
Kosovo, we suggest that firms can use social media for marketing purpose. Despite of the obtained research results, we suggest that SMEs should invest in training but by prioritising what kind of training is needed and selecting appropriately the training participants. In today's high-tech world SMEs need to offer specialised services and develop an innovative customer-focused strategy employing the new technologies (Gates, Myhrvold, \& Rinearson, 1995). By utilising the Internet, entrepreneurs can access online the very latest news, research findings, and innovations and embody them in practice. In this way, they gain the competitive advantage over their competitors in the market and increase the quality of their services/products. The importance of government on creating a supportive business environment for SMEs is crucial as it can identify and fight corruption, informality, weak administrative capacity, lack of access to finance, the deficient rule of law, and inadequate professional education. Kosovan firms must get the customers information at every possible touch point as Kotler and Armstrong (2012) suggests the use of this information is critical to investigate customer's behaviour, to understand their needs and preferences as well as buying habits.

\section{Limitations and further study}

Although our research is an important outcome that will contribute to the empirical evidence with the focus on determinants of firm's profitability in transitions countries, still it has some research limitations that lead us to future studies. First, our dependent variable (profitability) is not an exact figure taken from company accounts, but it is self-reported. Second, our research covers data only for one year, and it is not longitudinal research. Therefore, it lacks the time dimension to observing and investigating a phenomenon. Third, the BSCK survey questionnaire constituted was designed to analyse the profile of entrepreneurship and SMEs in Kosovo. It misses detailed questions regarding our four groups of research variables. Therefore, further research in this area is desirable to identify the push or pull factors toward IT adoption.

\section{References}

Acs, Z., \& Audretsch, D. (2001). The emergence o the entrepreneurial society, presentation for the acceptance of the 2001 ,. International Award for Entrepreneurship and Small Business Research. Stockholm.

Avdullahi, A., \& Fejza, V. (2015). The role of competitive strategies on developing a strong competitive advantage. Research Journal of Economics, Business and ICT, 10(2), 1-5.

Avdullahi, A. (2015). Obstacles to Small and Medium Enterprises. Horizons, 17, 67-76.

Bartlett, W., \& Bukivc, V. (2001). Barriers to SME Growth in Slovenia". MOCT-MOST, 11(2), 177-195. https://doi.org/10.1023/A:1012206414785 
Bartlett, W; Bateman, M; Vehovec, M. (2002). Small Enterprise Development in South-East Europe. Springer US. doi:10.1037/0021-9010.89.4.587

Baum, J. R., \& Locke, E. A. (2004). The relationship of entrepreneurial traits, skill, and motivation to subsequent venture growth. Journal of Applied Psychology, 89(4), 587-598. doi:10.1037/0021-9010.89.4.587

Bartelsman, E., \& Doms, M. (2000). Understanding productivity: lessons from longitudinal Micro Data. Journal of Economic Literature, 38(3), 569-594. doi:10.1257/jel.38.3.569

Becchetti, L., \& Trovato, G. (2002). The Determinants of Growth for Small and Medium Sized Firms. The Role of the Availability of External Finance". Small Business Economics, 19(4), 291-306. doi:10.1023/A:1019678429111

Beck, T., Kunt, D. A., Leaven, L., \& Maksimovic, V. (2006). The determinants of financing obstacles. Journal of International Money and Finance, 25(6), 932-952. doi:/10.1016/j.jimonfin.2006.07.005

Becker, G. S. (1975). Human Capital, National Bureau of Economic Research. New York: National bureau of economic research.

Bennett, J. (2010). Informal Firms in Developing Countries: Entrepreneurial Stepping Stone or Consolation Prize?",. Small Business Economics, 34(1), 53-63. doi:10.1007/s11187-0099194-6

Bharati, P., \& Chaudhury, A. (2006). Studying the Current Status, examining the extent and nature of adoption of technologies by micro, small and medium-sized manufacturing firms in the greater Boston area. Communications of the ACM, 49(10), 27-31. doi:10.1145/1164394.1164400

Biggs, T. (2003). Is Small Beautiful and Worthy of Subsidy? Literature Review Introduction, Washington IEG

Bohata, M., \& Mladek, J. (1999). The Development of the Czech SME Sector". Journal of Business Venturing, 14(5-6), 461-473. doi:10.1016/S0883-9026(98)00025-1

Box, T. M., White, M. A., \& Barr, S. H. (1994). A contingency model of new manufacturing performance". Entrepreneurship Theory \& Practice, 31-45. https://doi.org/10.1177/104225879401800202

BSCK. (2012). Entrepreneurship and small business development in Kosovo in 2011. Prishtina: BSC Kosovo. Retrieved from www.bsckosovo.org/publikimet/20121108044632244.pdf

BSCK. (2013). Entrepreneurship and small business development in Kosovo in 2012. Business Support Centre Kosova, Prishtina. Retrieved from www.bsckosovo.org/ publikimet/ 20140205055101250.pdf

Chrisman, J. J., Bauerschmidt, A., \& Hofner, C. W. (1998). The determinants of new venture performance: An extended model. Entrepreneurship: Theory and Practice, 5-29. doi:10.1007/s11187-009-9194-6

Chrisman, J. J., McMullan, E., \& Hall, J. (2005). The influence of guided preparation on the longterm performance of new ventures. Journal of Business Venturing, 20(6), 769-791. doi:10.1016/j.jbusvent.2004.10.001

Cliff, J. (1998). Does one size fit all? Exploring the relationship between attitudes toward growth, gender and business size1998. Journal of Business venturing, 13(6), 523-542. doi:10.1016/S0883-9026(97)00071-2 
Cooper, A. C., Gimeno-Gascon, F. J., \& Woo, C. Y. (1994). Initial human and financial capital as predictors of new venture performance. Journal of Business Venturing, 9(5), 371-395. doi:10.1016/0883-9026(94)90013-2

Corso, M., Martini, A., Pellegrini, L., \& Paolucci, E. (2003). Technological and organizational tools for knowledge management: in search of configurations". Small Business Economics, 21(4), 397-408. doi:10.1023/A:1026123322900

Cosh, A. D., Hughes, A., \& Weeks, M. (2000). The relationship between training and employment growth in small and medium-sized enterprises. UK: University of Cambridge: Centre for Business Research Working Paper. Retrieved from http://dera.ioe.ac.uk/ 4670/1/RR245.PDF

D`Souza, D. E., \& McDougall, P. P. (1989). Third world joint venturing: A strategic option for the smaller firm. Entrepreneurship Theory \& Practice, 13(4), 19-33. doi:10.1111/j.17416248.1993.00019.x

Dadashev, A., Glovatskaia, N., Lazurenko, S., \& Neshitoi, A. (2003). The effectiveness of support for small business Problems of Economic Transition. Taylor \& Francis Journals , 45(11), 69-83. Retrieved from https://www.tandfonline.com/ doi/abs/10.1080/10611991.2003.11049804

Delmar, F., Davidsson, P., \& Gartner, W. (2003). Arriving at the high-growth firm. Journal of Business Venturing, 18(3), 189-216. doi:10.1016/S0883-9026(02)00080-0

Drnevich, L. P., \& Carson, C. D. (2013). Information Technology and business level strategy toward an integrated theoretical perspective,. IT \& Business Strategy MIS Quarterly, 37(2), 483-509. doi:10.25300/MISQ/2013/37.2.08

Eisenhardt, K. M., \& Schoonhoven, C. B. (1990). Organizational growth: Linking founding team, strategy, environment, and growth among U.S. semiconductor ventures, 1978-1988. Administrative Science Quarterly, 35(3), 504-530. Retrieved from http://www.jstor.org/stable/2393315. https://doi.org/10.2307/2393315

Fejza, V., \& Bajrami, H. (2019). Marketing Analysis in the Water Production Sector in Kosovo. Case Study "Dea Water". International Journal of Business and Management, 59-79. doi:10.20472/BM.2019.7.2.005

Fjeldstad, O.-H., Kolstad, I., \& Nygaard, K. (2006). Bribes, taxes and regulations: Business constraints for micro enterprises in Tanzania. Chr. Michelsen Institute

Gates, B., Myhrvold, N., \& Rinearson, P. (1995). The road ahead, Viking Penguin,. New York, NY.

Gibrat, R. (1931). Les Ine'galite's E'conomiques",. Paris: Librairie du Recueil Sirey.

Gilbert, B. A., McDougall, P. P., \& Audretsch, B. D. (2006). New Venture Growth: A Review and Extension. Journal of Management, 32(6), 926-950. doi:10.1177/0149206306293860

Gimeno, J., Folta, T. B., Cooper, A. C., \& Woo, C. Y. (1997). Survival of the fittest?, Entrepreneurial human capital and the persistence of underperforming firms",. Administrative Science Quarterly, 42(4), 750-783. doi:10.2307/2393656

Hirsch, S., Schiefer, J., Gschwandtner, A., \& Hartmann, M. (2014). The Determinants of Firm Profitability Differences in EU Food Processing. Journal of Agricultural Economics, 65(3), 703-721. https://doi.org/10.1111/1477-9552.12061 
Hofer, C. W., \& Sonberg, W. R. (1987). Improving new venture performance: Some guidelines for success,. American Journal of Small Business, 11-25. https://doi.org/10.1177/104225878701200101

Hoxha, D. (2013). Understanding Small Business Growth and Development in Context of an Extreme, Transition and Marginalized Environment. Barcelona, Spain. Retrieved from www.tdx.cat/bitstream/handle/10803/125978/dh1de1.pdf

Isik, O., Unal, E. A., \& Unal, Y. (2017). The effects of firms size on profitability: Evidence from Turkish manufacturing sector. Journal of Business, Economics and Finance, 6(4), 301308. doi:10.17261/Pressacademia.2017.762

Jovanovic, B. (1982). Selection and evolution of industry". Econometrica, 50, 649-670. doi:10.2307/1912606

Kimberley, J. (1976). Issues in the design of longitudinal organizational research. Sociological Methods and Research, 4(3), 321-347. doi:10.1177/004912417600400303

Kontorovich, V. (1999). Has new business creation in Russia come to a halt? Journal of Business Venturing, 14(5-6), 451-460. doi:10.1016/S0883-9026(98)00030-5

Kotler, P., \& Armstrong, L. (2012). Principles of Marketing 14th ed. Boston: Pearson Prentice Hall.

Krasniqi, B. (2007). Barriers to entrepreneurship and SME growth in transition: The case of Kosovo". Journal of Developmental Entrepreneurship, 12(1), 71-94. doi:10.1142/S1084946707000563

Krasniqi, B. (2012). Building an Expanded Small Firm Growth Model in a Transitional Economy: Evidence on Fast Growing Firms,. Journal of East-West Business, 18(3), 231-273. doi:10.1080/10669868.2012.728903

Levasseur, C. (2002). Business Value of IT- Non-performance Measurements. International Edition ed. London Oxford printing press.

Levy, M., Powell, P., \& Yetton, P. (2001). SMEs: aligning IS and the strategic context”. Journal of Information Technology, 16(3), 133-144. doi:10.1080/0268396011

Lind, A. D., Mason, D. R., \& Marchall, G. W. (2000). Basic Statistics for Business and Economics, 3rd ed.,. Boston.: Irwin McGraw-Hill,.

Matejun, M. (2013). Instruments Supporting Development in the Life Cycle of Small and MediumSized Enterprises. International Journal of Economic Sciences, II(1), 40-60.

McPherson, M. A. (1996). Growth of micro and small enterprises in Southern Africa. Juornal of Development Economics, 48(2), 253-277. doi:10.1016/0304-3878(95)00027-5

Muent, H., Pissarides, F., \& Sanfey, P. (2001). Taxes, Competition and Finance for Albanian Enterprises: Evidence from a Field Study",. MOCT-MOST, 11(3), 239-251. doi:10.1023/A:101316121

Murphy, G. B., Trailer, J. W., \& Hill, R. C. (1996). Measuring performance in entrepreneurship research,. Journal of Business Research, 15-23. doi:10.1016/0148-2963(95)00159-X

Notta, O., \& Vlachvei, A. (2013). Web Site Utilization in SME Business Strategy: The Case of Greek Wine SMEs. World Journal of Social Sciences, 3(5), 131-141. 
Nguyen, T., Sherif, J., \& Newby, M. (2007). Strategies for successful CRM implementation".

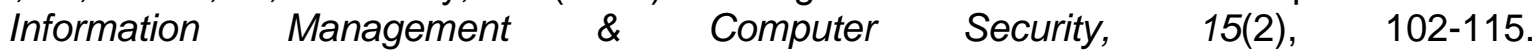
doi:10.1108/09685220710748001

North, C. D. (1990). Institutions, Institutional Change, and Economic Performance . Cambridge: University Press. https://doi.org/10.1017/CBO9780511808678

OECD. (2002). Annual Report. UK Embassy Bangkok: OECD. Retrieved from https:www.oedc. org /about/2080175.pdf

Pack, H., \& Westphal, L. (1986). Industrial strategy and technological change: Theory versus reality. Journal of Development Economics, 22(1), 87-128. doi:org/10.1016/03043878(86)90053-2

Peric , T. S., \& Kukec, S. K. (2013). The Role of Controlling for the Development of Planning, Information and Reporting Systems in SMEs. International Journal of Economic Sciences, 2(1), 82-100.

Pflugoeft, K. A., Ramamurth, K., Soofi, E. S., Yasai-Ardekani, M., \& Fatemah, M. (2003). Multiple Conceptualizations of Small Business Web Use and Benefit'. Decision Sciences, 34(3), 476-512. doi:10.1111/j.1540-5414.2003.02539.x

Pratt, J. H. (2002). E-Biz.com: Strategies for small busines success. Washington D.C.: SBA Office of Advocacy. Retrieved from http://purl.access.gpo.gov/GPO/LPS95423

Premkumar, G. (2003). A meta-analysis of research on information technology implementation in small business". Journal of Organizational Computing and Electronic Commerce, 13(2), 91-121. doi:10.1207/S15327744JOCE1302_2

Rufai , I. A. (2014). The impact of communication technologies on the performance of SMES in a developing economy: Nigeria as a case study. The Electronic Journal of Information Systems in Developing Countries, 65(7), 1-22. doi:10.1002/j.1681-4835.2014.tb00469.x

Siegel, R., Siegel, E., \& MacMillan, I. C. (1993). Characteristics are distinguishing high-growth ventures. Journal of Business Venturing, 8(2), 169-180. doi:10.1016/0883-9026(93)90018Z

Simmons, G., Armstrong, G. A., \& Durking, M. G. (2008). A conceptualization of the determinants of small business website adoption. International Small Business Journal, 26(3), 351-389. doi:10.1177/0266242608088743

Skenderi, N., Islami, X., \& Mulolli, E. (2017). The Impact of Informal Economy in the Development of SMEs - Evidence from Kosovo (2008-2012). International Journal of Management, Accounting and Economics, 4(5), 554-564.

Sosa, J., Roy, A., Bautista, A. (2015). Micro, Small and Medium Enterprises and Social Networks in Tourism Industry in Manzanillo, Colima, Mexico. International Journal of Business and Management, III(1), 90-104. https://doi.org/10.20472/BM.2015.3.1.006

Storey, D. J. (1994). Understanding the Small Business Sector. UK London: Chapman \& Hall,.

Wooldridge, J. (2006). Introductory Econometrics: A modern Approach, 3rd ed. USA: Cengage Learning;.

World Bank. (2007). Informality: Exit and exclusion. Washington, D C. Retrieved from http://siteresources.worldbank.org/ INTLAC/Resources/CH0.pdf 